International Journal of

Supply Chain

Management

(IJSCM)

INFLUENCE OF CONTRACT MANAGEMENT ON PERFORMANCE OF PUBLIC HOSPITALS IN NAIROBI CITY COUNTY, KENYA

Anne Wanjiru Karoki and Dr. Patrick Mwangangi

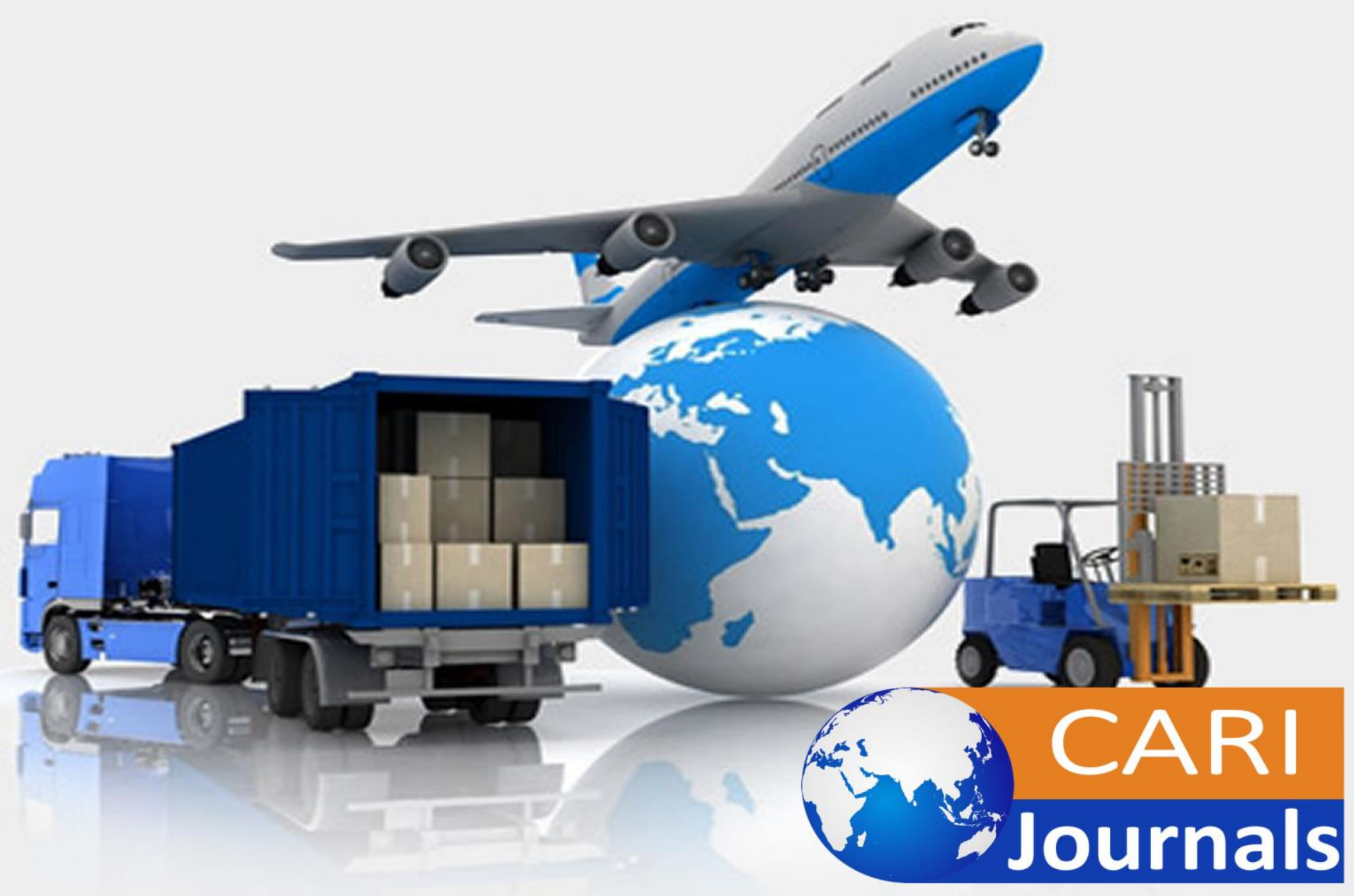


International Journal of Supply Chain and Logistics

ISSSN 2520-4661 (Online)

Vol. 4, Issue No.1, pp 46 - 69, 2020

$\underline{\text { www.carijournals.org }}$

\title{
Influence of Contract Management on Performance of Public Hospitals in Nairobi City County, Kenya
}

\author{
1*Anne Wanjiru Karoki \\ Post Graduate Student: Department of Procurement and Logistics, Jomo Kenyatta University of \\ Agriculture and Technology \\ *Corresponding Author's E-mail: wanjiruanne36@gmail.com \\ ${ }^{2}$ Dr. Patrick Mwangangi
}

Lecturer: Department of Procurement and Logistics, Jomo Kenyatta University of Agriculture and Technology

\begin{abstract}
Purpose: The study sought to establish the influence of contract management on performance of public hospitals in Nairobi City County, Kenya.

Methodology: This study employed descriptive research design. The study reviewed both theoretical and empirical literature and then proposed the research methodology that addressed the gaps identified in literature as well as to validate the statistical hypotheses. The researcher preferred this method because it allows an in-depth study of the subject. The study population was all public hospitals in Kenya. To gather data, structured questionnaire was used to collect data from 76 staff in procurement, administration and finance departments from the four largest public hospitals in Nairobi County; Kenyatta National Hospital, Mama Lucy Kibaki Hospital, Mbagathi District Hospital and Pumwani Maternity. The target population was all public hospitals in Nairobi City County. The target population was first stratified then using simple random sampling among the four strata, select the samples. The study combined two methods in its data collection that is, questionnaires and key informant interviews. After data collection, quantitative data was coded using Statistical Package for Social Science (SPSS) version 20. Data was analyzed through descriptive statistical methods such as means, standard deviation, frequencies and percentage. Inferential analysis was used in relation to correlation analysis and regression analysis to test the relationship between the four explanatory variables and the explained variable.
\end{abstract}

Findings: R square value of 0.647 means that $64.7 \%$ of the corresponding variation in performance of public hospitals in Kenya can be explained or predicted by (contract planning, monitoring and evaluation, contractor relationship management and dispute resolution) which indicated that the model fitted the study data. The results of regression analysis revealed that there was a significant positive relationship between dependent variable and independent variable at $(\beta$ $=0.647), p=0.000<0.05)$. The findings of the study concluded that contract planning, monitoring and evaluation, contractor relationship management, dispute resolution have a positive relationship with performance of public hospitals in Kenya. 
International Journal of Supply Chain and Logistics

ISSSN 2520-4661 (Online)

Vol. 4, Issue No.1, pp 46 - 69, 2020

$\underline{\text { www.carijournals.org }}$

Unique contribution to theory, practice and policy: The study recommended that public institutions should embrace contract management practices so as to improve performance and further researches should to be carried out in other public institutions to find out if the same results can be obtained.

Keywords: Contract planning, monitoring and evaluation, contractor relationship management, dispute resolution, performance, public hospitals.

\subsection{INTRODUCTION}

Contract management improves an organization's operational performance as indicated by various measures, such as, quality, flexibility, speed, efficiency, and supplier relationship (Cho \& Pucick, 2015).Contract management may be defined as the process that ensures both parties to a contract fully meet their respective obligations as efficiently and influence as possible, in order to deliver the business and operational objectives required from the contract and in particular to provide value for money (Nguyen, 2013).

As a result, developing and managing contracts is a skill required by almost all public sector entities. Rendon (2010) affirm that the quintessence of contract management evolves proper planning, award, and administration of contracts and the monitoring of providers' performance. Once this is deficient, it increases the risk of endangering value for money. Recently corruption has turned out to be one of the most challenging phenomena of our time that can easily make the process of contract management unsuccessful (Cropper, 2016). Contract management entails efforts by the immediate parties to a transaction to align incentives and craft governance structures that are better attuned to their exchange needs and due allowance being made for the mitigation of contractual hazards (Enquist, Johnson \& Camén, 2013).

Out of awareness that workers are not passive contractual agents, naïve efforts which focus entirely on intended influences will be supplanted by more sophisticated mechanisms where provision is made for consequences of both kinds (Rönnberg-Sjödin, 2013). More generally, the awareness that organizations have a life of their own serves to uncover a variety of behavioral regularities for which stakeholders should be alerted and thereafter factored into the organizational design (Smith, 2014).

\subsection{Problem Statement}

Ideally, public hospitals support the Government of Kenya's health policy of ensuring that health services are easily accessible and affordable to $90 \%$ of Kenyan citizens hence the reason for the national and county government's heavy funding amounting to Ksh. 152 Billion through annual budgetary allocation that aims at ensuring that the hospitals have a steady supply of drugs and other essential supplies. Despite this, public health facilities in Kenya have over time, been blamed for poor service delivery and performance in general $(\mathrm{MoH}, 2015)$. As a result, the sector has seen a reduction in its contribution to GDP from 14\% in the early 2000 's to 8\% in 2012, (RoK, 2013). Contract management in state agencies is important as these organizations use $70 \%$ of taxpayer money for their operations (Deloitte, 2012). 
International Journal of Supply Chain and Logistics

ISSSN 2520-4661 (Online)

Vol. 4, Issue No.1, pp 46 - 69, 2020

$\underline{\text { www.carijournals.org }}$

According to an OECD Report (2011) the public hospitals play a major role in the health status and index of a country through provision of public health services and very useful engines to promoting development. Nevertheless, most public hospitals in Kenya operate at a technical efficiency of about $42 \%$ compared to their counterparts in Asia that average about $82 \%$ (USAID, 2012) raising doubts about the sector's capacity to meet the goals of Vision 2030.In Kenya, 80\% of public hospitals have been blamed for poor services emanating from contract parties not complying and performing as per the agreement (PPOA, 2009). Other issues noted include errors, payment, specifications, policy specifications, as well as any changes that may result in the course of the contract execution (USAID, 2012).

According to a report by Center for Health Solutions (2014) on public hospitals in Kenya, losses of Kshs. 66 million were incurred through inappropriate change management in contract management especially change in scope and scale of works in financial year (FY) 2011/2012. This raises questions on the level of performance of public hospitals' contract management system as a public institution (MoH, 2013). According to a spend analysis report by Kirungu (2014), public hospitals lost Ksh.350 million due to stalled dispute resolution regarding adherence to time schedule which consequently affected its performance as a whole.

A research carried out on the state of service delivery in health and education facilities in Kenya by Africare International (2014) revealed that $80 \%$ of public health facilities have inadequate essential supplies. The study also found that the public preferred private hospitals to public hospitals due to the perception that private hospitals have a ready supply of drugs and essential supplies despite the high costs of services (KIPPRA, 2010). Locally, Abdifatah (2012) did a study on contract management and concluded that they have direct positive impact on the performance of humanitarian organizations in delivery of relief and emergency services.

While much research has focused on the problems facing contract management in public organizations in Kenya, not much research has been done to study contract management and performance of public hospitals in Kenya. It is against this back drop that this study aims at assessing the influence of contract management on performance of public hospitals in Nairobi City County, Kenya, with particular focus on public hospitals.

\subsection{Objectives of the Study}

i. To examine the influence of contract planning on performance of public hospitals in Nairobi City County, Kenya.

ii. To establish the influence of monitoring and evaluation on performance of public hospitals in Nairobi City County, Kenya.

iii. To determine the influence of contractor relationship management on performance of public hospitals in Nairobi City County, Kenya.

iv. To evaluate the influence of dispute resolution on performance of public hospitals in Nairobi City County, Kenya. 
International Journal of Supply Chain and Logistics

ISSSN 2520-4661 (Online)

Vol. 4, Issue No.1, pp 46 - 69, 2020

$\underline{\text { www.carijournals.org }}$

\subsection{LITERATURE REVIEW}

\subsection{Contract Compliance Theory}

Contract compliance theory is the act of conforming to contract agreements between buyers and sellers. Generally, he purchasing function is held responsible for all reasons of non-compliance. According Aberdeen Group (2006) compliance may be internal or external. Internal compliance can be interpreted as either conforming to the rules in the agreement by purchasing organization such as payment terms and minimum order requirements or in purchasing from agreement only, that is, purchasing by using framework agreements for the entire company (Telgen, 2004).According to Aberdeen Group (2006) the use of framework agreements for the entire company can assist maintaining high contract compliance and reduction in purchasing costs. This can in turn increase the probability of procurement processes success. As far as the procurement processes as concerned, external contract compliance can take up several forms including unavailability of products services or qualified personnel, charging prices different from the contracted prices, or late delivery or delivering products that do not meet the contracted specifications.

\subsection{Contract Management}

\subsubsection{Contract Planning}

Contract planning involves having an advance strategy regarding; controlling and managing contract variations; paying the contractor; managing assets; drafting reports; and terminating the contract (Hansson \& Longva, 2014; Piga \& Treumer, 2013). Contract planning, the formal governance of the contract, is concerned with the mechanics of the relationship between the parties. The implementation of procedures defining the interface between them and the smooth operation of routine administrative and clerical functions; and contract planning includes such tasks as change management and handover policy, charges and cost monitoring, ordering and payment schedules, management reporting, and so on (OGC, 2012)

\subsubsection{Monitoring and Evaluation}

Technical contract management starts with contractor monitoring and acceptance management. This is vital in enabling the contracting organization to ascertain that the contractor is undertaking his duties and fulfilling his obligations in compliance with the contract. This also allows the contracting organization to pinpoint any issues or problems in advance that could arise and offer timely solutions. Particularly, the outline of contractor monitoring and acceptance management includes: monitoring, controlling, and evaluating the contractor's performance; evaluating the quantity and cost minimization, works, or products delivered; and identifying and handling risks (Cropper, 2008). The eight key levers that constitute the economic frame of the procurement processes' business deal, and notes that in order achieve a success, for any parties, it is essential to understand these business drivers which specify the basic content of the deal, and give assurances for both sides (Branconi \& Loch, 2013). 
International Journal of Supply Chain and Logistics

ISSSN 2520-4661 (Online)

Vol. 4, Issue No.1, pp 46 - 69, 2020

$\underline{\text { www.carijournals.org }}$

\subsubsection{Contractor Relationship Management}

Contract management involves managing the contractor relationship. This refers to the actions and initiatives of the contracting company to create and maintain a positive relationship with the contractor (Piga \& Treumer, 2013). This depends on the mutual trust, understanding, regular communication and timely management of possible problems in the contract. Thirdly, the practice includes contract planning. This procedure involves maintaining an updated form of the contract; controlling and managing contract variations; paying the contractor; managing assets; drafting reports; and terminating the contract (Hansson \& Longva, 2014).

\subsubsection{Dispute Resolution}

Conflict is defined as any action or circumstance resulting from incompatible or opposing needs (Peña-Mora, 2013). A significant characteristic of conflict is that it usually presents two incompatible possibilities at the same time that result in difficulty for either party to make a choice (Fisher, 2014). Cheung and Suen (2002) stated that Disputes are inevitable in construction procurement processes and Dispute Resolution Procedures such as litigation, arbitration, mediation, dispute adviser and negotiation are widely practiced. A decision-making model was created using the Analytical Hierarchy Process (AHP) and Multi-Attribute Utility Technique (MAUT). The model comprises four parts: selection criteria, dispute resolution strategies, collection of utility factors and selection criteria weightings. These were gathered from an empirical data collected through an interview survey with selected experts in the field.

\subsection{Research Gaps}

A research carried out on the state of service delivery in health and education facilities in Kenya by Africare International (2014) revealed that $80 \%$ of public health facilities have inadequate essential supplies. The study also found that the public preferred private hospitals to public hospitals due to the perception that private hospitals have a ready supply of drugs and essential supplies despite the high costs of services (KIPPRA, 2010). Locally, Abdifatah (2012) did a study on contract management and concluded that they have direct positive impact on the performance of humanitarian organizations in delivery of relief and emergency services.

While much research has focused on the problems facing contract management in public organizations in Kenya, not much research has been done to study contract management and performance of public hospitals in Kenya. It is against this back drop that this study aims at assessing the influence of contract management on performance of public hospitals in Nairobi City County, Kenya, with particular focus on public hospitals.

\subsection{Conceptual Framework}

\begin{tabular}{|l|l|}
\hline Contract Planning \\
- Change Management \\
- Payment Schedules \\
- Handover Policy
\end{tabular}


International Journal of Supply Chain and Logistics

ISSSN 2520-4661 (Online)

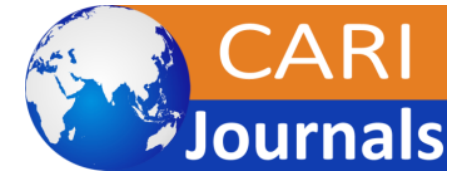

Vol. 4, Issue No.1, pp 46 - 69, 2020

www.carijournals.org

\begin{tabular}{|c|}
\hline $\begin{array}{l}\text { Monitoring and Evaluation } \\
\text { - } \quad \text { Progress and Milestones Reports } \\
\text { - Incentives and Consequences Policy } \\
\text { - Contingency Plans }\end{array}$ \\
\hline $\begin{array}{c}\text { Contractor Relationship Management } \\
\text { - } \quad \text { Regular Communication } \\
\text { - } \quad \text { Strategic Collaborations } \\
\text { - } \quad \text { Early Contractor Involvement }\end{array}$ \\
\hline $\begin{array}{cc}\text { Dispute Resolution } \\
\text { - } \\
\text { - } & \text { Arbitration } \\
\text { - } & \text { Litigation }\end{array}$ \\
\hline
\end{tabular}

Independent Variables
Dependent Variable

\section{Figure 1: Conceptual Framework}

\subsection{METHODOLOGY}

This study employed descriptive research design. The study reviewed both theoretical and empirical literature and then proposed the research methodology that addressed the gaps identified in literature as well as to validate the statistical hypotheses. The researcher preferred this method because it allows an in-depth study of the subject. The study population was all public hospitals in Kenya. To gather data, structured questionnaire was used to collect data from 76 staff in procurement, administration and finance departments from the four largest public hospitals in Nairobi County; Kenyatta National Hospital, Mama Lucy Kibaki Hospital, Mbagathi District Hospital and Pumwani Maternity. The target population was all public hospitals in Nairobi City County. The target population was first stratified then using simple random sampling among the four strata, select the samples. The study combined two methods in its data collection that is, questionnaires and key informant interviews. After data collection, quantitative data was coded using Statistical Package for Social Science (SPSS) version 20. Data was analyzed through descriptive statistical methods such as means, standard deviation, frequencies and percentage. Inferential analysis which involved correlation analysis and regression analysis was used to test the causal relationship between the four explanatory variables and the explained variable.

\subsection{DATA ANALYSIS AND PRESENTATION}

\subsection{Introduction}

This chapter presents results arising from the analysis of data collected using questionnaires. 
International Journal of Supply Chain and Logistics

ISSSN 2520-4661 (Online)

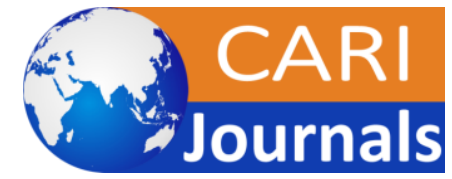

Vol. 4, Issue No.1, pp 46 - 69, 2020

www.carijournals.org

\subsection{Response Rate}

A sample of respondents were interviewed using questionnaires that allowed the study to drop the questionnaires to the respondents and then collect them at a later date when they had filled the questionnaires. A total of 76 questionnares were distributed to employees. Out of the population covered, 76 were responsive respresenting a response rate of $100 \%$. This was above the $50 \%$ which is considered adequate in descriptive statistics according to (Kothari, 2014).

Table 1: Response Rate of Respondents

\begin{tabular}{lll}
\hline Response & Frequency & Percentage \\
\hline Actual Response & 76 & 100 \\
Non-Response & 0 & 0 \\
Total & 76 & $100 \%$ \\
\hline
\end{tabular}

\subsection{Pilot results}

The cronbach's alpha was computed in terms of the average inter-correlations among the items measuring the concepts. The rule of thumb for cronbach's alpha is that the closer the alpha is to 1 the higher the reliability (Neuman, 2010). A value of at least 0.7 is recommended. Cronbach's alpha is the most commonly used coefficient of internal consistency and stability. Consistency indicated how well the items measuring the concepts hang together as a set. Cronbach's alpha was used to measure realibilty. This was done on the four objectives of the study. The higher the coefficient, the more reliable is the test.

Table 2: Reliability Results

\begin{tabular}{lllll}
\hline Variable & No. of Items & Respondents & a=Alpha & Comment \\
\hline Contract Planning & 9 & 8 & 0.893 & Reliable \\
Monitoring and Evaluation & 9 & 8 & 0.987 & Reliable \\
Contractor Relationship Management & 9 & 8 & 0.974 & Reliable \\
Dispute Resolution & 9 & 8 & 0.976 & Reliable \\
\hline
\end{tabular}

\subsection{Demographic Information}

\subsubsection{Distribution of Respondents by Gender}

The study determined the gender distribution of the respondents. The results summarized in the figure below. The results revealed that majority of the respondent $(51 \%)$ indicated that they were male, while only (49\%) of the respondent indicated that they were female. The percentages may raise the issue of gender equity in public hospitals in this country, but that is outside the scope of this study. A study on UK companies found that women and men do not differ in their ability to 
International Journal of Supply Chain and Logistics

ISSSN 2520-4661 (Online)

Vol. 4, Issue No.1, pp 46 - 69, 2020

www.carijournals.org

perform operational tasks, but rather bring a different perspective to strategic decision making in procurement (Gianakis, 2012).

\section{Gender}

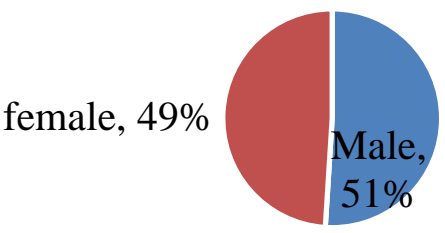

Figure 2: Distribution of Respondents by Gender

\subsubsection{Distribution of Respondents by Age}

The study determined the distribution of respondents by age. The results summarized in the table below. The results revealed that majority of the respondent (42\%) were 18-30 years old, (32\%) were 31-40 years old, while (16\%) were between $41-50$ years. 50 years and above were (10\%). The findings are in agreement with those of Hall (2014) who established that there are two natural age peaks of the early $30 \mathrm{~s}$ and mid $40 \mathrm{~s}$ which correlated to employee performance and consequential performance of public hospitals.

Table 3: Distribution of Respondents by Age

\begin{tabular}{lll}
\hline Years & Frequency & Percent \\
\hline 18-30 Years & 32 & 42 \\
31-40 Years & 24 & 32 \\
41-50 Years & 12 & 16 \\
50 Years and above & 8 & 10 \\
Total & $\mathbf{7 6}$ & $\mathbf{1 0 0}$ \\
\hline
\end{tabular}

\subsubsection{Distribution of Respondents by Level of Education}

The respondents were asked to state their highest level of education and the results revealed that majority of the respondent $(71 \%)$ indicated that their academic qualification was up to undergraduate level. The result further revealed that $(16 \%)$ of the respondent indicated that their academic qualification was up to master level. Diplomas were (13\%) With majority respondents having degree and above, it is expected that their level of understanding of performance of public hospitals is good. This is an indication that the results obtained from respondents interviewed in the present study can be relied upon. These findings concur those of Hatry (2016) who established that majority of who run public procurement are highly educated and that there is evidence linking education and performance in public hospitals.

\section{Table 4: Distribution of Respondents by Level of Education}


International Journal of Supply Chain and Logistics

ISSSN 2520-4661 (Online)

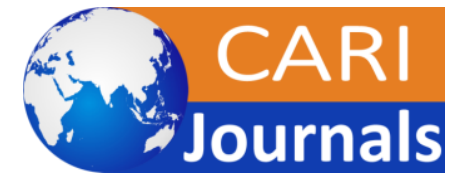

Vol. 4, Issue No.1, pp 46 - 69, 2020

www.carijournals.org

\begin{tabular}{lll}
\hline Education Level & Frequency & Percent \\
\hline Diploma & 10 & 13 \\
Undergraduate & 54 & 71 \\
Post-Graduate & 12 & 16 \\
Total & $\mathbf{7 6}$ & $\mathbf{1 0 0}$ \\
\hline
\end{tabular}

\subsubsection{Distribution of Respondents by Length of Service}

The study determined the number of years the respondents had worked in their current office. The respondents were asked to indicate their work duration. The result revealed that majority of the respondents $(45 \%)$ indicated that their work duration was 6-8 years. The result also showed that $(11 \%)$ of the respondent indicated that their work duration was 9 and above years above. 0-2 years had (13\%), 3-5 years had (31\%) The findings of the study are in tandem with literature review by Joiner (2012) who indicated that a duration and experience of employee helps him or her to have better knowledge and skills which contribute to procurement performance.

Table 5: Distribution of Respondents by Length of Service

\begin{tabular}{lll}
\hline Length of Service & Frequency & Percent \\
\hline 0-2 Years & 10 & 13 \\
3-5 Years & 24 & 31 \\
6-8 Years & 34 & 45 \\
9 Years and above & 8 & 11 \\
Total & $\mathbf{7 6}$ & $\mathbf{1 0 0 . 0}$ \\
\hline
\end{tabular}

\subsection{Descriptive Statistics}

The study set out to examine the influence of contract management on performance of public hospitalsin Kenya. To this end, four variables were conceptualized as components of contract management among public hospitals in Kenya. These included; contract planning, monitoring and evaluation, contractor relationship management and dispute resolution.

\subsubsection{Contract Planning}

The first objective of the study was to assess the influence of contract planning on performance of public hospitals in Kenya. The respondents were asked to indicate to what extent contract planning affected performance among public hospitals in Kenya. Results indicated that majority of the respondents $27 \%$ agreed that it was to a very effective, $25 \%$ said that it was effective, $29 \%$ said it was somehow effective, while ineffective was at $19 \%$. 
International Journal of Supply Chain and Logistics

ISSSN 2520-4661 (Online)

Vol. 4, Issue No.1, pp 46 - 69, 2020

$\underline{\text { www.carijournals.org }}$

\section{Contract Planning}

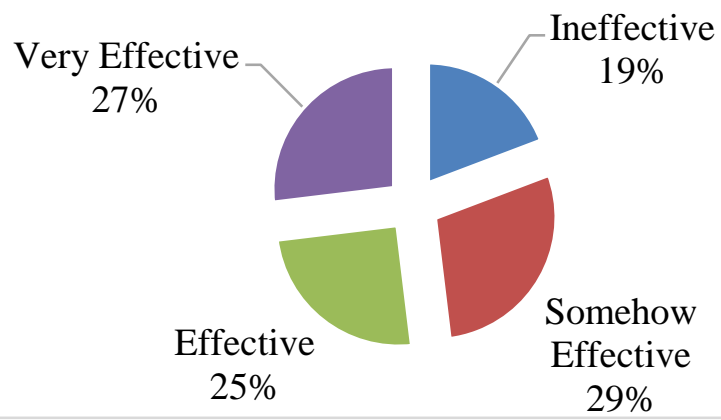

\section{Figure 3: Contract Planning}

The respondents were also asked to comment on statements regarding contract planning influence on performance among public hospitals in Kenya. The responses were rated on a Likert scale and the results presented in Table 6 below. It was rated on a 5-point Likert scale ranging from; $1=$ strongly disagree to $5=$ strongly agree. The scores of 'strongly disagree' and 'disagree' have been taken to represent a statement not agreed upon, equivalent to mean score of 0 to 2.5. The score of 'neutral' has been taken to represent a statement agreed upon, equivalent to a mean score of 2.6 to 3.4. The score of 'agree' and 'strongly agree' have been taken to represent a statement highly agreed upon equivalent to a mean score of 3.5 to 5 .

The respondents were asked to indicate their responses on influence of contract planning on performance of public hospitals in Kenya. The results revealed that majority of the respondent with a mean of (4.13) agreed with the statement that change management plays a significant role in timely service delivery. The measure of dispersion around the mean of the statements was 0.94 indicating the responses were varied. The result revealed that majority of the respondent as indicated by a mean of (4.27) agreed with the statement payment schedules plays a significant role in timely service delivery. The standard deviation for was 0.968 showing a variation. The result revealed that majority of the respondent (4.55) agreed with the statement that handover policy play a significant role in timely service delivery. The results were varied as shown by a standard deviation of 0.5 .

The average response for the statements on change management plays a great role in cost minimization was (4.22). The results were varied as shown by a standard deviation of 0.955 . The average response for the statements on payment schedules plays a great role in cost minimization was (4.4). The results were varied as shown by a standard deviation of 0.704 . The result revealed that majority of the respondent with a mean of (4.46) agreed with the statement that handover policy plays a great role in cost minimization. The measure of dispersion around the mean of the statements was 0.787 indicating the responses were varied.

The result revealed that majority of the respondent as indicated by a mean of (4.44) agreed with the statement change management plays a great role in improving customer satisfaction. The standard deviation for was 0.786 showing a variation. The result revealed that majority of the 
International Journal of Supply Chain and Logistics

ISSSN 2520-4661 (Online)

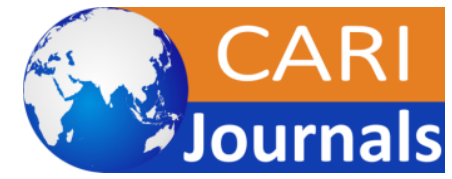

Vol. 4, Issue No.1, pp 46 - 69, 2020

www.carijournals.org

respondent (4.21) agreed with the statement that payment schedules play a great role in improving customer satisfaction. The results were varied as shown by a standard deviation of 0.942 . The average response for the statements on handover policy plays a great role in improving customer satisfaction was (4.01). The results were varied as shown by a standard deviation of 0.81 .

The average mean of all the statements was 4.01 indicating that majority of the respondents agreed on contract planninghaving an influence on performance of public hospitals in Kenya. However, the variations in the responses were varied as shown by a standard deviation of 0.81 . These findings imply that contract planningwas at the heart of the organizations. The findings agree with Kinyanjui (2010) that using contract planning as contract management practice is a smart move and can reduce expenses significantly.

Table 6: Contract Planning

\begin{tabular}{lcc}
\hline Statements & Mean & Std. Deviation \\
\hline Change management plays a great role in timely service delivery & 4.10 & 0.94 \\
Payment schedules plays a great role in timely service delivery & 4.27 & 0.968 \\
Handover policy plays a great role in timely service delivery & 4.55 & 0.500 \\
Change management plays a great role in cost minimization & 4.22 & 0.955 \\
Payment schedules plays a great role in cost minimization & 4.41 & 0.704 \\
Handover policy plays a great role in cost minimization & 4.46 & 0.787 \\
Change management plays a great role in improving customer & & \\
satisfaction & 4.44 & 0.786 \\
Payment schedules plays a great role in improving customer & & \\
satisfaction & 4.21 & 0.942 \\
Handover policy plays a great role in improving customer & & \\
satisfaction & 4.11 & 1.096 \\
Average & $\mathbf{4 . 0 1}$ & $\mathbf{0 . 8 1}$ \\
\hline
\end{tabular}

\subsubsection{Monitoring and Evaluation}

The second objective of the study was to establish the influence of monitoring and evaluation on performance of public hospitals in Kenya. The respondents were asked to indicate to what extent monitoring and evaluation influenced performance of public hospitals in Kenya. Results indicated that majority of the respondents $25 \%$ agreed that it was to a very great extent, $27 \%$ said that it was to a great extent, $35 \%$ said it was moderate, while little extent and not all were at $5 \%$ and $8 \%$ respectively. 
International Journal of Supply Chain and Logistics

ISSSN 2520-4661 (Online)

Vol. 4, Issue No.1, pp 46 - 69, 2020

$\underline{\text { www.carijournals.org }}$

\section{Monitoring and Evaluation}

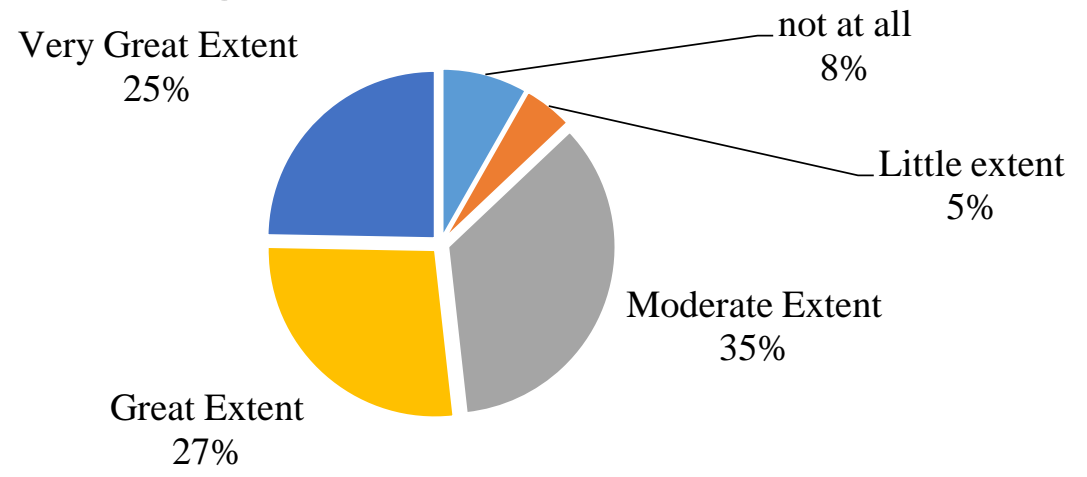

Figure 4: Monitoring and Evaluation

The respondents were also asked to comment on statements regardingmonitoring and evaluation on performance of public hospitals in Kenya. The results revealed that majority of the respondent with a mean of (3.58) agreed with the statement that progress and milestone reports play a significant role in timely service delivery. The measure of dispersion around the mean of the statements was 1.0 indicating the responses were varied. The result revealed that majority of the respondent as indicated by a mean of (3.63) agreed with the statement incentives and consequences play a significant role in timely service delivery. The standard deviation for was 0.9 showing a variation. The result revealed that majority of the respondent (3.6) agreed with the statement that contingency channels play a significant role in timely service delivery. The results were varied as shown by a standard deviation of 0.7 .

The average response for the statements on progress and milestone reports plays a great role in cost minimization was (3.45). The results were varied as shown by a standard deviation of 1.2. The average responses for the statements on incentives and consequences policy plays a great role in cost minimization was (3.5). The results were varied as shown by a standard deviation of 1.0. The results revealed that majority of the respondent with a mean of (3.61) agreed with the statement that contingency channels play a great role in cost minimization. The measure of dispersion around the mean of the statements was 0.6 indicating the responses were varied.

The result revealed that majority of the respondent as indicated by a mean of (4.17) agreed with the statement progress and milestone reports play a great role in improving customer satisfaction. The standard deviation for was 0.8 showing a variation. The result revealed that majority of the respondent (3.63) agreed with the statement that incentives and consequences policy play a great role in improving customer satisfaction. The results were varied as shown by a standard deviation of 0.8. The average response for the statements on contingency channels plays a great role in improving customer satisfaction was (3.66). The results were varied as shown by a standard deviation of 1 .

The average mean of all the statements was 3.77 indicating that majority of the respondents agreed on monitoring and evaluation having an influence on performance of public hospitals in Kenya. 
However, the variations in the responses were varied as shown by a standard deviation of 1.134. These findings agree with Kirungu (2012) that through monitoring and evaluation, organizations can improve competitive positioning.

Table 7: Monitoring and Evaluation

\begin{tabular}{lcc}
\hline Statements & Mean & Std. Deviation \\
\hline $\begin{array}{l}\text { Progress and milestone reports plays a great role in timely service } \\
\text { delivery }\end{array}$ & 3.58 & 1.0 \\
$\begin{array}{l}\text { Incentives and consequences policy play a great role in timely service } \\
\text { delivery }\end{array}$ & 3.63 & 0.9 \\
$\begin{array}{l}\text { Contingency channels play a great role in timely service delivery } \\
\text { Progress and milestone reports plays a great role in cost minimization }\end{array}$ & 3.6 & 0.7 \\
$\begin{array}{l}\text { Incentives and consequences policy play a great role in cost } \\
\text { minimization }\end{array}$ & 3.5 & 1.2 \\
$\begin{array}{l}\text { Contingency channels play a great role in cost minimization } \\
\text { Progress and milestone reports plays a great role in improving } \\
\text { customer satisfaction }\end{array}$ & 3.61 & 0.6 \\
$\begin{array}{l}\text { Incentives and consequences policy play a great role in improving } \\
\text { customer satisfaction }\end{array}$ & 4.17 & 0.8 \\
$\begin{array}{l}\text { Contingency channels play a great role in improving customer } \\
\text { satisfaction }\end{array}$ & 3.63 & 0.8 \\
Average & 3.66 & 1.0 \\
\hline
\end{tabular}

\subsubsection{Contractor Relationship Management}

There was also need to establish influence of contractor relationship managementon performance of public hospitals in Kenya as the third objective. Results indicated that majority of the respondents $47 \%$ agreed that it was to a very great extent, $45 \%$ said that it was to a great extent, $2 \%$ said it was moderate; little extent was $2 \%$ and not all at $4 \%$.

\section{Contractor Relationship Management}

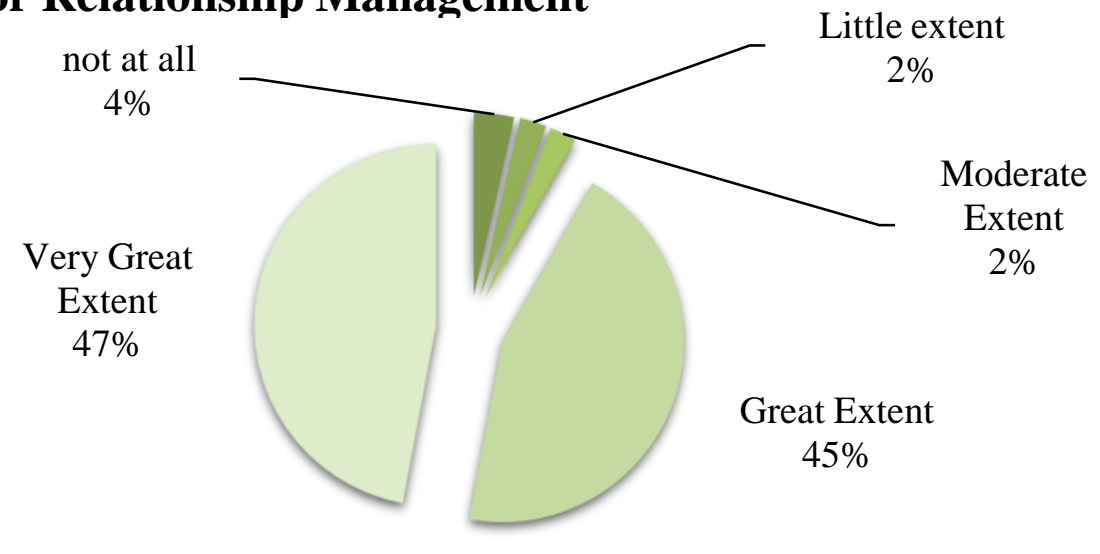


International Journal of Supply Chain and Logistics

ISSSN 2520-4661 (Online)

Vol. 4, Issue No.1, pp 46 - 69, 2020

$\underline{\text { www.carijournals.org }}$

\section{Figure 5: Contractor Relationship Management}

The respondents were asked to indicate their levels of agreement on statements regarding contractor relationship management. The results revealed that majority of the respondents with a mean of (3.8) agreed with the statement that regular communicationplays a significant role in timely service delivery. The measure of dispersion around the mean of the statements was 0.9 indicating the responses were varied. The result revealed that majority of the respondent as indicated by a mean of (4.9) agreed with the statement strategic collaborationsplay a significant role in timely service delivery. The standard deviation for was 0.9 showing a variation. The result revealed that majority of the respondent (3.4) agreed with the statement that early contractor involvementplays a significant role in timely service delivery. The results were varied as shown by a standard deviation of 1.3 .

The average response for the statements on regular communication plays a great role in cost minimization was (3.6). The results were varied as shown by a standard deviation of 1.2. The average response for the statements on strategic collaborations plays a great role in cost minimization was (4.1). The results were varied as shown by a standard deviation 0.8 . The results revealed that majority of the respondent with a mean of (4.1) agreed with early contractor involvement play a great role in cost minimization. The measure of dispersion around the mean of the statements was 0.9 indicating the responses were varied.

The result revealed that majority of the respondent as indicated by a mean of (4) agreed with the statement regular communication plays a great role in improving customer satisfaction. The standard deviation for was 1 showing a variation. The result revealed that majority of the respondent (4.2) agreed with the statement that strategic collaborations play a great role in improving customer satisfaction. The results were varied as shown by a standard deviation of 0.8 . The average response for the statements on early contractor involvement plays a great role in improving customer satisfaction was (3.9). The results were varied as shown by a standard deviation of 0.9 .

Average mean of all the statements was 3.8 indicating that majority of the respondents agreed on contractor relationship management having an influence on performance of public hospitals in Kenya. However, the variations in the responses were varied as shown by a standard deviation of 0.9. The results are in tandem with Lin and Lee (2011) who opine that an organization benefits greatly when contractor relationship management is embraced in their procurement department.

Table 8: Contractor Relationship Management

\begin{tabular}{lcc}
\hline Statements & Mean & Std. Deviation \\
\hline Regular communication plays a great role in timely service delivery & 3.8 & 0.9 \\
Strategic collaborations play a great role in timely service delivery & 4.9 & 0.9 \\
Early contractor involvement plays a great role in timely service & & \\
delivery & 3.4 & 1.3 \\
Regular communication plays a great role in cost minimization & 3.6 & 1.2 \\
Strategic collaborations play a great role in cost minimization & 4.1 & 0.8
\end{tabular}


International Journal of Supply Chain and Logistics

ISSSN 2520-4661 (Online)

Vol. 4, Issue No.1, pp 46 - 69, 2020

$\underline{\text { www.carijournals.org }}$

Early contractor involvement plays a great role in cost minimization

Regular communication plays a great role in improving customer satisfaction

4.1

0.9

Strategic collaborations play a great role in improving customer satisfaction

Early contractor involvement plays a great role in improving customer satisfaction

$4.2 \quad 0.8$

Average

0.9

\subsubsection{Dispute Resolution}

There was also need to establish the influence of dispute resolutionon performance of public hospitals in Kenya. Results also showed that $3 \%$ of respondents indicated to very great extent, great extent was at $12 \%$, moderate extent was $37 \%$, while little extent was at $27 \%$ and not at all was at $21 \%$.

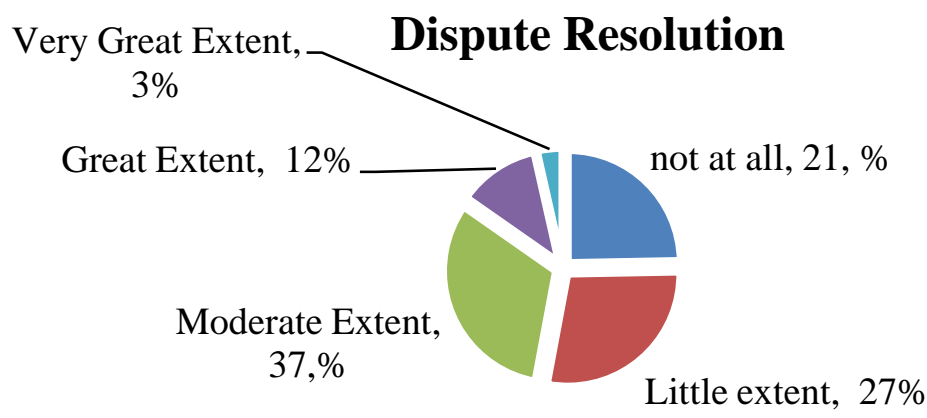

\section{Figure 6: Dispute Resolution}

The respondents were asked to indicate their views on dispute resolution. The results revealed that majority of the respondent with a mean of (4.5) agreed with the statement that arbitration plays a significant role in timely service delivery. The measure of dispersion around the mean of the statements was 0.5 . The result revealed that majority of the respondent as indicated by a mean of (3.9) agreed with the statement mediation plays a significant role in timely service delivery the standard deviation for was 0.8 showing a variation. The result revealed that majority of the respondent (3.2) agreed with the statement that litigation plays a significant role in timely service delivery. The results were varied as shown by a standard deviation of 1.4. The average response for the statements on arbitration plays a great role in cost minimization was (4.5). The results were varied as shown by a standard deviation of 0.5 . The average response for the statements on mediation plays a great role in cost minimization was (4.4). The results were varied as shown by a standard deviation 0.6. The results revealed that majority of the respondent with a mean of (4.4) agreed with the statement litigation play a great role in cost minimization. The measure of dispersion around the mean of the statements was 0.9 indicating the responses were varied.

The result revealed that majority of the respondent as indicated by a mean of (4.3) agreed with the statement Arbitration plays a great role in improving customer satisfaction. The standard deviation 
International Journal of Supply Chain and Logistics

ISSSN 2520-4661 (Online)

Vol. 4, Issue No.1, pp 46 - 69, 2020

www.carijournals.org

for was 0.7 showing a variation. The result revealed that majority of the respondent (4.5) agreed with the statement that Mediation plays a great role in improving customer satisfaction. The results were varied as shown by a standard deviation of 1.0. The average response for the statements on Litigation play a great role in improving customer satisfaction was (4.1). The results were varied as shown by a standard deviation of 1.0. Average mean of all the statements was 4.2 indicating that majority of the respondents agreed on dispute resolutionhaving an influence on performance of public hospitals in Kenya. However, the variations in the responses were varied as shown by a standard deviation of 0.8 . The results agree with Muge (2013) that an organization that embraces dispute resolutionbenefits greatly in its operations.

\section{Table 9: Dispute Resolution}

\begin{tabular}{lcc}
\hline Statements & Mean & Std. Deviation \\
\hline Arbitration plays a great role in timely service delivery & 4.5 & 0.5 \\
Mediation plays a great role in timely service delivery & 3.9 & 0.8 \\
Litigation play a great role in timely service delivery & 3.2 & 1.4 \\
Arbitration plays a great role in cost minimization & 4.5 & 0.5 \\
Mediation plays a great role in cost minimization & 4.4 & 0.6 \\
Litigation play a great role in cost minimization & 4.4 & 0.9 \\
Arbitration plays a great role in improving customer satisfaction & 4.3 & 0.7 \\
Mediation plays a great role in improving customer satisfaction & 4.2 & 1.0 \\
Litigation play a great role in improving customer satisfaction & 4.1 & 1.0 \\
Average & $\mathbf{4 . 2}$ & $\mathbf{0 . 8}$ \\
\hline
\end{tabular}

\subsection{Correlation Analysis}

Correlation analysis was used to determine both the significance and degree of association of the variables and also predict the level of variation in the dependent variable caused by the independent variables. The correlation summary shown in Table 10 indicates that the associations between each of the independent variables and the dependent variable were all significant at the $95 \%$ confidence level. The correlation analysis to determine the relationship between contract management and performance of public hospitals in Kenya, Pearson correlation coefficient computed and tested at $5 \%$ significance level.

The results indicate that there is a positive relationship $(\mathrm{r}=.509)$ between contract planning and performance of public hospitals in Kenya. In addition, the researcher found the relationship to be statistically significant at $5 \%$ level $(\mathrm{p}=0.000,<0.05)$. The results also indicate that there is a positive relationship $(\mathrm{r}=.398)$ between monitoring and evaluation and performance of public hospitals in Kenya. In addition, the researcher found the relationship to be statistically significant at $5 \%$ level $(\mathrm{p}=0.000,<0.05)$. The results indicate that there is a positive relationship $(\mathrm{r}=.678)$ between contractor relationship managementand performance of public hospitals in Kenya. In addition, the researcher found the relationship to be statistically significant at $5 \%$ level ( $\mathrm{p}=0.000$, 
<0.05). The results indicate that there is a positive relationship ( $\mathrm{r}=.685)$ between dispute resolutionand performance of public hospitalsin Kenya. In addition, the researcher found the relationship to be statistically significant at $5 \%$ level $(\mathrm{p}=0.000,<0.05)$. Hence, it is evident that all the independent variables could explain the changes in performance of public hospitals in Kenya, on the basis of the correlation analysis.

Table 10: Summary of Pearson's Correlations

\begin{tabular}{|c|c|c|c|c|c|c|}
\hline Correlations & & $\begin{array}{l}\text { Contract } \\
\text { Planning } \\
\end{array}$ & $\begin{array}{c}\text { Monitoring } \\
\text { and } \\
\text { Evaluation }\end{array}$ & $\begin{array}{c}\text { Contractor } \\
\text { Relationship } \\
\text { Management } \\
\end{array}$ & $\begin{array}{c}\text { Dispute } \\
\text { Resoluti } \\
\text { on } \\
\end{array}$ & $\begin{array}{c}\text { Performance } \\
\text { of Public } \\
\text { Hospitals } \\
\end{array}$ \\
\hline $\begin{array}{l}\text { Performance } \\
\text { of Public } \\
\text { Hospitals }\end{array}$ & $\begin{array}{l}\text { Pearson } \\
\text { Correlation }\end{array}$ & 1 & & & & \\
\hline $\begin{array}{l}\text { Contract } \\
\text { Planning }\end{array}$ & $\begin{array}{l}\text { Sig. (2-Tailed) } \\
\text { Pearson } \\
\text { Correlation } \\
\text { Sig. (2- } \\
\text { Tailed) }\end{array}$ & $\begin{array}{l}.263 * * \\
0.007\end{array}$ & 1 & & & \\
\hline $\begin{array}{l}\text { Monitoring } \\
\text { and }\end{array}$ & Pearson & & & & & \\
\hline Evaluation & $\begin{array}{l}\text { Correlation } \\
\text { Sig. (2- } \\
\text { Tailed) }\end{array}$ & $\begin{array}{l}.350 * * \\
0.000\end{array}$ & $\begin{array}{l}.346 * * \\
0.000\end{array}$ & 1 & & \\
\hline $\begin{array}{l}\text { Contractor } \\
\text { Relationship } \\
\text { Management }\end{array}$ & $\begin{array}{l}\text { Pearson } \\
\text { Correlation }\end{array}$ & $.363 * *$ & $.516^{* *}$ & $.543 * *$ & 1 & \\
\hline
\end{tabular}


International Journal of Supply Chain and Logistics

ISSSN 2520-4661 (Online)

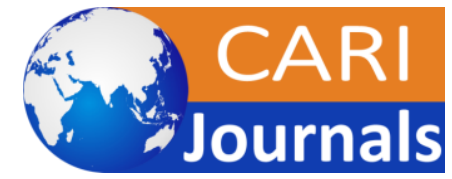

Vol. 4, Issue No.1, pp 46 - 69, 2020

www.carijournals.org

\begin{tabular}{|c|c|c|c|c|c|c|}
\hline & $\begin{array}{l}\text { Sig. } \\
\text { Tailed) }\end{array}$ & 0.000 & 0.000 & 0.000 & & \\
\hline Dispute & Pearson & & & & & \\
\hline Resolution & Correlation & $.509 * *$ & $.398 * *$ & $.678 * *$ & $.685^{* *}$ & 1 \\
\hline Contract & Sig. $\quad$ (2- & & & & & \\
\hline Planning & Tailed) & 0.000 & 0.000 & 0.000 & 0.000 & \\
\hline
\end{tabular}

** Correlation is Significant at the 0.05 Level (2-Tailed).

\subsection{Regression Analysis}

In this study multivariate regression analysis was used to determine the significance of the relationship between the dependent variable and all the independent variables pooled together. Regression analysis was conducted to find the proportion in the dependent variable (performance of public hospitals) which can be predicted from the independent variables (contract planning, monitoring and evaluation, contractor relationship management and dispute resolution).

Table 11 presents the regression coefficient of independent variables against dependent variable. The results of regression analysis revealed there is a significant positive relationship between dependent variable and the independent variable. R square value of 0.647 means that $64.7 \%$ of the corresponding variation in performance of public hospitals in Kenya can be explained or predicted by (contract planning, monitoring and evaluation, contractor relationship management and dispute resolution) which indicated that the model fitted the study data. The results of regression analysis revealed that there was a significant positive relationship between dependent variable and independent variable at $(\beta=0.647), \mathrm{p}=0.000<0.05)$.

Table 11: Model Summary

\begin{tabular}{llllll}
\hline Model & R & R Square & Adjusted R Square & $\begin{array}{l}\text { Std. Error of the } \\
\text { Estimate }\end{array}$ & \\
\hline 1 & $.805^{\mathrm{a}}$ & .647 & .633 & .166295 \\
\hline
\end{tabular}

Table 12: ANOVA

\begin{tabular}{|c|c|c|c|c|c|c|}
\hline Model & & $\begin{array}{l}\text { Sum } \\
\text { Squares }\end{array}$ & of $\mathrm{df}$ & Mean Square & $\mathbf{F}$ & Sig. \\
\hline \multirow[t]{3}{*}{1} & Regression & 5.027 & 4 & 1.257 & 33.078 & $.000^{\mathrm{b}}$ \\
\hline & Residual & 2.738 & 71 & 0.038 & & \\
\hline & Total & 7.765 & 75 & & & \\
\hline
\end{tabular}

The significance value is 0.000 which is less than 0.05 thus the model is statistically significance in predicting how contract planning, monitoring and evaluation, contractor relationship management and dispute resolution affect performance of public hospitals in Kenya. The F critical at 5\% level of significance was 23.5. Since F calculated which can be noted from the ANOVA table above is 33.078 which is greater than the F critical (value=23.5), this shows that the overall model was significant. The study therefore establishes that; contract planning, monitoring and 
International Journal of Supply Chain and Logistics

ISSSN 2520-4661 (Online)

Vol. 4, Issue No.1, pp 46 - 69, 2020

$\underline{\text { www.carijournals.org }}$

evaluation, contractor relationship management and dispute resolution were all important contract management aspects influencing performance of public hospitals. These results agree with Rotich (2011) results which indicated a positive and significant influence of prudent contract management on performance of public hospitals.

Table 13: Coefficients of Determination

\begin{tabular}{|c|c|c|c|c|c|c|}
\hline \multicolumn{2}{|c|}{ Model } & \multicolumn{2}{|c|}{$\begin{array}{l}\text { Unstandardized } \\
\text { Coefficients }\end{array}$} & \multirow{2}{*}{$\begin{array}{c}\begin{array}{c}\text { Standardized } \\
\text { Coefficients }\end{array} \\
\text { Beta }\end{array}$} & \multirow[t]{2}{*}{$\mathbf{t}$} & \multirow[t]{2}{*}{ Sig. } \\
\hline & & $\boldsymbol{\beta}$ & $\begin{array}{c}\text { Std. } \\
\text { Error }\end{array}$ & & & \\
\hline \multirow[t]{5}{*}{1} & (Constant) & 2.353 & 0.202 & & 11.69 & 0.000 \\
\hline & Contract Planning & 0.183 & 0.037 & 0.392 & 4.948 & 0.000 \\
\hline & $\begin{array}{l}\text { Monitoring } \\
\text { Evaluation }\end{array}$ & 0.158 & 0.045 & 0.232 & 3.546 & 0.001 \\
\hline & $\begin{array}{l}\text { Contractor Relationship } \\
\text { Management }\end{array}$ & 0.121 & 0.023 & 0.383 & 5.272 & 0.000 \\
\hline & Dispute Resolution & 0.001 & 0.036 & 0.001 & 0.027 & 0.040 \\
\hline
\end{tabular}

The research used a multiple regression model

$$
\mathrm{Y}=\boldsymbol{\beta}_{0}+\boldsymbol{\beta}_{1} \mathrm{X}_{1}+\boldsymbol{\beta}_{2} \mathrm{X}_{2}+\boldsymbol{\beta}_{3} \mathrm{X}_{3}+\boldsymbol{\beta}_{4} \mathrm{X}_{4}+\mathcal{E}
$$

The regression equation is as follows;

$$
Y=2.353+0.183 X_{1}+0.158 X_{2}+0.121 X_{3}+0.001 X_{4}
$$

The regression equation above has established that taking all factors into account (contract planning, monitoring and evaluation, contractor relationship management and dispute resolution) constant at zero, performance of public hospitals in Kenya will be an index of 2.353. The findings presented also shows that taking all other independent variables at zero, a unit increase in contract planning will lead to a 0.183 increase in performance of public hospitals. The P-value was 0.000 which is less 0.05 and thus the relationship was significant.

The study also found that a unit increase in monitoring and evaluation will lead to a 0.158 increase in performance public hospitals. The P-value was 0.001 and thus the relationship was significant. In addition, the study found that a unit increase in contractor relationship managementwill lead to a 0.121 increase in performance of public hospitals. The P-value was 0.000 and thus the relationship was significant.

Lastly, the study found that dispute resolution will lead to a 0.001 increase in performance of public hospitals. The P-value was 0.04 and hence the relationship was significant since the $\mathrm{p}$-value was lower than 0.05 . The findings of the study show that, contract planning contributed most to the performance of public hospitals. 
International Journal of Supply Chain and Logistics

ISSSN 2520-4661 (Online)

Vol. 4, Issue No.1, pp 46 - 69, 2020

$\underline{\text { www.carijournals.org }}$

\subsection{SUMMARY, CONCLUSION AND RECOMMENDATIONS}

\subsection{Summary of the Findings}

The regression equation above has established that taking all factors into account (contract planning, monitoring and evaluation, contractor relationship management and dispute resolution) constant at zero, performance of public hospitals in Kenya will be an index of 2.353. The findings presented also shows that taking all other independent variables at zero, a unit increase in contract planning will lead to a 0.183 increase in performance of public hospitals. The P-value was 0.000 which is less 0.05 and thus the relationship was significant.

The study also found that a unit increase in monitoring and evaluation will lead to a 0.158 increase in performance public hospitals. The P-value was 0.001 and thus the relationship was significant. In addition, the study found that a unit increase in contractor relationship management will lead to a 0.121 increase in performance of public hospitals. The P-value was 0.000 and thus the relationship was significant.

Lastly, the study found that dispute resolution will lead to a 0.001 increase in performance of public hospitals. The P-value was 0.04 and hence the relationship was significant since the p-value was lower than 0.05 . The findings of the study show that, contract planning contributed most to the performance of public hospitals.

\subsection{Conclusion}

The findings of the study concluded that contract planning, monitoring and evaluation, contractor relationship management, dispute resolution have a positive relationship with performance of public hospitals in Kenya.

\subsection{Recommendations}

The study recommended that public institutions should embrace contract management practices so as to improve performance and further researches should to be carried out in other public institutions to find out if the same results can be obtained.

\section{REFERENCES}

Abouzeedan, A., \& Busler, M. (2012). Information technology (IT) Impact on Performance of Small and Medium-size Enterprises (SMEs) 16th Work Shop. Barcelona, Spain, 2(1), 22-28.

Aitken, J., Childerhouse, P., \& Towill, D. (2008). The impact of product life cycle on supply chain strategy. International Journal of Production Economics, 85(2), 127-140.

Belz, C., \& Wuensche, M. (2009). "Classification of performance contracting solutions: a managerial typology", paper presented at the 2nd International Conference on Business Market Management.

Bjorkman, M. (2006). Public Funding in the Educational Sector and Its Influence on Test Scores in Essays on Empirical Development Economics: Education, Health and Gender, IIES Monograph Series No 56, Stockholm University. 
International Journal of Supply Chain and Logistics

ISSSN 2520-4661 (Online)

Vol. 4, Issue No.1, pp 46 - 69, 2020

www.carijournals.org

Cheung, C.F., Wang, W.M., \& Lo, V., (2014). An agent oriented and knowledge-based system for strategic e-procurement. Expert Systems, 21(1), 11-19.

Choi, T.Y., \& Krause,D. (2008). "The supply base and its complexity: Implications for transaction costs, risks, responsiveness, and innovation". Journal of Operations Management, 2(4), 637652.

Chris, M., \& Adam, D. (2009). "Using SPC to measure a national supermarket chain's suppliers' performance", International Journal of Operations \& Production Management, 27(8), 874900

Christopher, M., \& Peck, H. (2014). "Building the Resilient Supply Chain". International Journal of Logistics Management, 15(2), 1-13.

CIPS (2008). How do we measure up? An Introduction to Performance Measurement of the Procurement Profession. Retrieved September 17, 2017, from Chartered Institute of Purchasing and Supply.

Cox, A., (2008). Understanding buyer and supplier power: a framework for procurement and supply competence. The Journal of Supply Chain Management 37(2), 8-15.

Cox, A., Lonsdale, C., Watson, G., \& Wu, Y. (2010). Supplier relationship management as an investment: evidence from UK study, Journal of General Management, 30(4), 27-42.

Danese, P., Romano, P., \& Formentini, M. (2013). The Impact of Supply Chain Integration on Responsiveness: The Moderating Influence of using an International Supplier Network. Transportation Research 49(1), 125-140.

Dean, A.M., \& Kiu, C. (2012). "Performance monitoring and quality outcomes in contracted services", International Journal of Quality \& Reliability Management, 19(4), 396-413.

Desouza, K.C. (2008). The neglected dimension in strategic sourcing: security, Strategic outsourcing: An international journal, 1(3), 288-292.

Dorward, A. (2010). "The influences of transaction costs, power and risk on contractual arrangements: a conceptual framework for quantitative analysis", Journal of Agricultural Economics, 52(2), 59-73.

Dyer, J.H., \& Nobeoka, K. (2010). "Creating and managing a high-performance knowledgesharing network: the Toyota case", Strategic Management Journal, 21(3), 345-367.

Edler, J., \& Georghiou, L. (2010). Public procurement and innovation. Resurrecting the demand side. Research Policy, 3(6), 949-963.

Evenett, S.J., \& Hoekman, B.M., (2014). International disciplines on government procurement: a review of economic analyses and their implications, Centre for Economic Policy Research, 4(3), 24-38.

Fisher, M.L., \& Mcclelland, A.S. (2010). "Rocket Science Retailing is Almost Here: Are You Ready?" Harvard Business Review Journal,78(4), 115-124. 
International Journal of Supply Chain and Logistics

ISSSN 2520-4661 (Online)

Vol. 4, Issue No.1, pp 46 - 69, 2020

www.carijournals.org

Gianakis, G. (2012). “The promise of public sector performance measurement: anodyne or placebo?" Public Administration Quarterly, 2(6), 34-64.

Golafshani, N. (2008). Understanding Reliability and Validity in Qualitative Research, The Qualitative Report, 8(4), 597-607.

Greiling, D. (2008). Performance measurement: a remedy for increasing the efficiency of Public services. International Journal of Productivity and Performance Management, 55(6), 448-465.

Handfield, R.B., \& Bechtel, C. (2012). The role of trust and relationship structure in improving supply chain responsiveness. Journal of Industrial Marketing Management, 31(4), 367-382.

Harrison, A., \& Hoek, R.I. (2011). Logistics management and strategy: competing through the supply chain. [rev.] ed. Harlow: Pearson/Financial Times Prentice Hall.

Heinrich, C.J. (2012). Outcomes-based performance management in the public sector: Implications for government accountability and effectiveness. Public Administration Rev. 62(6), 712-725.

Holweg, M. (2009). "An Investigation into Supplier Responsiveness". International Journal of Logistics Management, 16(1), 96-119.

Hoole, R. (2008). Five ways to simplify your supply chain, Emerald.

Humphreys, P., Li, W., \& Chan, L. (2014). The impact of supplier development on buyer-supplier performance, The International Journal of Management Science, 3(2), 131-143.

James, H., \& Faizul, H. (2010). From arms-length to collaborative relationships in the supply chain: An Evolutionary process. International Journal of Physical Distribution\& Logistics Management,3(9), 750-764.

Joash, M., \& Peterson, M. (2012). Synergies in African business and management practices. International Journal of Physical Distribution \& Logistics Management, 27(1), 39-52.

Johnson, R.B., \& Onwuegbuzie, A.J. (2008). Mixed Methods Research: A Research Paradigm Whose Time Has Come, Educational Researcher, 33(7), 14-26.

Kakwezi, P., \& Nyeko, S., (2010). Procurement Processes and Performance: Efficiency and Effectiveness of the Procurement Function: Makerere University Press, Kampala.

Kannan, V.R., \& Tan, K.C. (2009). Buyer-supplier relationships, The impact of supplier selection and buyer-supplier engagement on relationship and firm performance. International Journal of Physical Distribution \& Logistics Management, 36(10), 755-786.

Kasomo, D. (2009). Research Methods in Humanities and Education, Eldoret; Zapf Chancery.

Kazakhstann, J.R. \& Jakob, S. (2010). Survey Tools for Assessing Performance in Service Delivery. In the Impact of Economic Policies on Poverty and Income Distribution: Evaluation Techniques and Tools, edited by François. 
International Journal of Supply Chain and Logistics

ISSSN 2520-4661 (Online)

Vol. 4, Issue No.1, pp 46 - 69, 2020

www.carijournals.org

Klakegg, O.J., \& Williams, T. (2008). “Governance frameworks for public procurement processes development and estimation.” Procurement processes Management Journal, 3(9), 27-42.

Kombo, D., \& Tromp, D. (2010). Project and Thesis Writing, an introduction. Nairobi: Pauline Publications Africa.

Kothari, C.R. (2009). Research methodology: Methods and Techniques. 2Ed, New Age International.

Kumar, R., \& Markeset, T. (2008). "Development of performance-based service strategies for the oil and gas industry: a case study", Journal of Business \& Industrial Marketing, 2(2), 4-18.

Kusek, J., \& Rist, C. (2014). Ten Steps to a Results-based Monitoring and Evaluation System: A Handbook for procurement processes managers. World Bank Publications.

Larry, H. (2013). Advanced Statistics in Research: Reading, Understanding, and Writing Up Data Analysis Results. Publisher: Shadow Finch Media LLC.

Lazear, E. P. (2010). Performance pay and productivity. Amer. Econom. Rev. 90(5), 1346-1361.

Liker, J., \& Choi, T. (2010). Building deep supplier relationships. Harvard business review on supply chain management.

Matanda, M.J. \& Ndubisi, N.O. (2009). "Market orientation, supplier perceived value and business performance of SMEs in a Sub-Saharan African nation", Journal of Enterprise Information Management, 22(4), 384-407.

Mohan, G. (2010). Participatory Development. In Desai, Vandana and Potter, Rob eds. The Arnold Companion to development studies. London, UK.

Ngechu, M. (2009). Understanding the Research Process and Methods. An Introduction to Research Methods. Acts press, Nairobi.

Ngugi, J.K. \& Mugo H.W. (2012). Internal factors affecting procurement process of supplies in the public sector; a survey of Kenya government ministries. Paper presented at 5th International Public Procurement Conference. Seattle, USA.

OECD. (2010). Integrity in Public Procurement: Mapping out Good Practices for Integrity and Corruption Resistance in Public Procurement.

Omboi, B.M., \& Kariuki, F.K. (2011). Factors Affecting Implementation of Performance Contract Initiative at Municipal Council of Maua-Kenya. Research Journal of Finance and Accounting, 2(2), 9-10.

Ondieki, J. N, \& Oteki, E.B., (2015). Influence of supplier relationship management on the effectiveness of supply chain management in the Kenya public sector. International Journal of Managing Value and Supply Chains, 6(1), 100-118.

Oso, Y. \& Onen, D. (2009). A general Guide to Writing Research Project and Report. Kisumu: Options Printers and Publishers. 
International Journal of Supply Chain and Logistics

ISSSN 2520-4661 (Online)

Vol. 4, Issue No.1, pp 46 - 69, 2020

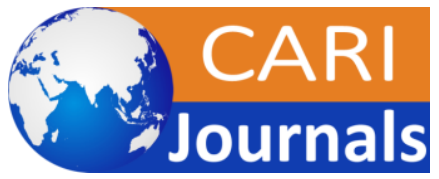

www.carijournals.org

Paul, D., Benn, L. \& Brian, S. (2008). "Performance measurement in strategic buyer-supplier relationships: The mediating role of socialization mechanisms", International Journal of Operations \& Production Management, 28(3), 238-258.

PPOA. (2010). Assessing Procurement Systems in Kenya Report. Nairobi: Public Oversight Authority.

PPRA (2015). Procurement Audit Report for 30 Procuring Entities, retrieved from http://www.ppra.go.tz on 28/09/2012. 